\title{
Secondary Structure of the Ribosomal Internal Transcribed Spacer (ITS) Region of Hypsizygus marmoreus
}

\author{
Ju-Ri Woo', Hyeokjun Yoon', Young-Hyun You', Chang-Yun Lee ${ }^{2}$, Won-Sik Kong ${ }^{3}$ and Jong-Guk Kim* \\ ${ }^{1}$ School of Life Sciences, Kyungpook National University, Daegu 702-701, Korea \\ ${ }^{2}$ Greenpeace Mushroom Ca, Cheongdo, GyeongBuk 714-852, Korea \\ ${ }^{3}$ Mushroom Research Division, NIHHS, RDA, Eumseang 714-853, Korea
}

Received July 12, 2013 /Revised October 4, 2013 /Accepted October 7, 2013

\begin{abstract}
The ribosomal DNA (rDNA) clusters of Hypsizygus marmoreus 3-10 and H. marmoreus 1-1 were analyzed in this study. The small subunit (SSU) and intergenic spacer 2 (IGS 2) was partially sequenced. The internal transcribed spacer 1 (ITS 1), 5.8S, internal transcribed spacer 2 (ITS 2), large subunit (LSU), intergenic spacer 1 (IGS 1), and 5S were completely sequenced. The rDNA clusters of $H$. marmoreus 3-10 and H. marmoreus 1-1 were 7,049 bp in length. The sequence of SSU rDNA, which corresponded to $18 \mathrm{~S}$ rDNA, was 1,796 bp in length, and the sequence of LSU rDNA, which corresponded to $28 \mathrm{~S}$ rDNA, was 3,348 bp in length. The ITS region that variable region and IGS region that nontranscribed spacer was $462 \mathrm{bp}$ and 1,290 bp in length. The sequence of 5.8S rDNA and 5S rDNA was $153 \mathrm{bp}$ and $43 \mathrm{bp}$ in length, respectively. The $17 \mathrm{bp}$ of the rDNA cluster in the H. marmoreus 3-10 strain was different to that in the $H$. marmoreus $1-1$ strain, with 2 bp in the SSU, 3 bp in the ITS, 9 $\mathrm{bp}$ in the LSU, and $3 \mathrm{bp}$ in the IGS. The analysis of the secondary structure revealed that the ITS regions of $H$. marmoreus 3-10 and $H$. marmoreus 1-1 have five stem-loop structures. Interestingly, among these structures, one different nucleotide sequence resulted in a different secondary structure in stem-loop $\mathrm{V}$.
\end{abstract}

Key words : Hypsizygus marmoreus, rDNA cluster, ITS region, secondary structure

\section{서 론}

버섯(Mushroom)은 약 15,000 종 정도가 전세계적으로 분포 하고 있으며, 식용 가능한 버섯은 약 2,000종으로 알려져 있다. 자연계에서 분해자 역할을 하는 버섯은 예로부터 식용 및 약 용으로 널리 이용되어왔으며 $[2,13,17,21]$, 버섯에 대한 연구 가 활발히 이루어진 결과, 항암활성, 면역활성, 항진균 활성, 항종양 효과 등을 가지는 여러 종류의 생리활성 물질들이 밝 혀졌다[3,10, 14, 22].

느티만가닥[Hypsizygus marmoreus (Peck.) Bigelow]버섯은 너도밤나무, 단풍나무, 고목 줄기나 그루터기에 군생하는 버 섯이다. 최근에, 영양학적인 가치뿐 아니라 독특한 맛과 질감, 긴 저장성 덕분에 수출용 버섯으로 각광받기 시작하였으며, 경제적 가치가 뛰어난 버섯이라 할 수 있겠다. 다발성이 강한 것이 특징인 이 버섯의 갓은 둥근 반구 형태를 보이다가 퇴화 가 일어나면서 평평하게 벌어지며, 가운데가 대리석 모양의

\footnotetext{
*Corresponding author

Tel : +82-53-950-5379, Fax : +82-53-955-5379

E-mail : Kimjg@knu.ac.kr

This is an Open-Access article distributed under the terms of the Creative Commons Attribution Non-Commercial License (http://creativecommons.org/licenses/by-nc/3.0) which permits unrestricted non-commercial use, distribution, and reproduction in any medium, provided the original work is properly cited.
}

독특한 담회색 색깔을 나타낸다. 주름은 백색이며 조밀한 조 직이 특징이다. 분류학적으로 담자균류(Basidiomycetes), 주 름버섯목(Agaricales), 송이과(Tricholomataceae)에 속하며 일 본에서는 bunashimeji 또는 honshimeji로 불려지며, 서양에서 는 winter mushroom으로 알려져 있다[4, 15]. 한국을 비롯한 동아시아 지역과 유럽에 주로 분포하고 있으며, 전세계적으로 1972년 이후 꾸준하게 생산량이 증가해왔다[13].

일반적으로 식용버섯의 대부분은 셀룰로오스, 헤미셀룰로 오스, 리그닌 등을 분해하여 영양분을 얻는 목재 부후균으로 자연으로부터 얻은 영양분을 통하여 자실체로 생장함으로 특 용임산물로 생각되어 왔으나, 현재는 인공재배법이 개발되어 대량생산이 가능하게 되었다. 느티만가닥버섯은 팽이버섯과 같이 일본에서 처음으로 인공재배가 성공하였으며, 국내에 생 산 기술이 보급되었다. 현재, 병 재배 시스템을 이용한 대량 생산이 이루어지고 있으며, 그 덕분에 생산량이 증가하고 있 는 추세이다.

지금까지, rDNA cluster는 다양한 분자적 수준의 접근 방법 을 통한 생물 종의 계통학적 유연관계 분석에 성공적으로 사 용되어왔다[21, 23]. ITS 1 과 ITS 2 영역은 변이가 적게 일어나 는 $18 \mathrm{~S} \mathrm{rDNA}$ 에 비해, 변이가 많이 일어나므로 종속 구별에 유용하다 $[2,11,12,19,20,24]$. 특히 이 영역은 500 600 bp 정도로 사이즈가 작아 손쉽게 분석이 가능하며 단순성, 일반 성, 재현성 등의 이점으로 종간 유전변이 탐색 등을 위해 널리 
이용되었다[4]. 따라서 ITS 영역은 분자생물학적 수준에서 생 물 종 간, 종 내에서의 차이를 확인하고자 사용되는 tool임이 틀림없다[23].

현재, 세계는 국제 분쟁으로 인한 여러 사례가 급격히 증가 하고 있다. 환경, 무역, 통상 등 여러 가지 분쟁이 발생되고 있으며, 미래 식량자원으로 각광 받는 버섯도 예외일수는 없 게 되었다. 우리나라뿐만 아니라 중국, 일본에서도 느티만가 닥 버섯이 생산 및 수출입 되고 있는 상황에서 국가 간 분쟁에 대비하여야 하는 시점이 되었다. 국내에서 생산된 느티만가닥 버섯은 대부분 일본 품종을 사용하고 있지만, 몇몇 업체에서 국내 개발 품종을 사용하고 있다. 수출 시장에서 일본 품종이 우세한 위치에 있기 때문에 국내 개발 균주에 대한 보호가 중요한 상황이 되었으나, 이에 따른 연구가 미비한 실정이다. 또한 다양한 느티만가닥버섯 균주를 구별하기 위한 쉽고 간단 하며 효과적인 방법의 개발이 중요하다[10].

우리나라는 중위도 온대성 기후대에 위치해 있으며 여름에 는 고온 다습하며 겨울에는 춥고 건조한 날씨를 나타내는 반 면, 일본은 섬나라이기 때문에 지리적으로 남북의 차이뿐 아 니라 바깥 일본과 안 일본 간의 기후 차이가 심하며 여름 겨울 의 연간 기후도 현저한 차이를 보인다고 알려져 있다. 이런 환경적 차이에도 불구하고, 느티만가닥버섯은 형태학적 측면 에서 육안으로 구별하기가 쉽지 않음으로, 분자생물학적 수준 에서 차이를 확인하고자 하였다. 현재까지 느티만가닥버섯의 지리학적 차이에 기초한 균주 간의 차이를 확인하고자 한 연 구는 이루어진 바 없다. 따라서 H. marmoreus 3-10 균주와 $H$. marmoreus 1-1 균주가 비록, 종속은 같을지라도 지리학적으로 큰 차이가 있음으로 $\mathrm{rDNA}$ 의 ITS region에 기초한 유전 정보 차이를 확인하여, 국가간 분쟁에 대비할 기초 자료를 마련하 고자 하였다.

본 연구에서는 국내 덕유산에서 채집된 $H$ marmoreus 3-10 균주와 일본 후쿠오카에서 채집된 H. marmoreus 1-1 균주 간의 차이를 확인 위하여, Ribosomal DNA (rDNA) cluster 서열을 분석하여, 이들 간의 분자적 수준에서의 차이를 밝히고자 하 였으며, $\mathrm{rDNA}$ 영역의 서열을 확보한 후 2차구조 분석을 수행 하였다.

\section{재료 및 방법}

\section{느티만가닥 균주 배양}

본 연구에서 사용된 느티만가닥버섯 H. marmoreus 3-10의 기원은 전북 덕유산이며, H marmoreus 1-1은 일본 후쿠오카에 서 채집되었다. 두 균주는 그린 합명회사에서 보존하고 있는 균사체를 분양 받아 실험에 사용하였으며, Potato dextrose agar (PDA; potato peptone $4.0 \mathrm{~g}$, glucose $20.0 \mathrm{~g}$ and agar powder $15.0 \mathrm{~g}, 11$ distilled water, Scharlau Chemie S.A, Spain) 배지로 $24^{\circ} \mathrm{C}, 13$ 일간 배양하고, Potato dextrose broth
(PDB; Potato peptone $4.0 \mathrm{~g}$, Glucose $20.0 \mathrm{~g}$ were dissolved 11 of distilled water $\mathrm{pH} 5.6$ and sterilized by autoclaving at $121^{\circ} \mathrm{C}$ for $15 \mathrm{~min}$ ) 액체배지에서 15 일간 $24^{\circ} \mathrm{C}, 80 \mathrm{rpm}$ 으로 배양하였다. DNA manipulation에 사용된 Eschericia coli strain은 DH5 a (Donginbiotech Co.)로 pGEM-T plasmid vector는 cloning과 sequencing에 사용되었다.

\section{느티만가닥버섯의 DNA extraction과 PCR amplification}

MÖller등의 방법[16]을 이용하여, $H$ marmoreus 3-10 균주 와 H. marmoreus 1-1 균주의 Genomic DNA를 추출하였다. 약 $4.0 \mathrm{~g}$ 의 자실체를 막자 사발을 이용하여 액체질소 첨가 후, 10 분동안 물리적으로 파쇄하였다. $15 \mathrm{ml}$ 의 lysis buffer $(20$ $\mathrm{mM}$ Tris-HCl (pH 8.0), $10 \mathrm{mM}$ EDTA, $1 \% \mathrm{SDS}$ ) 처리 후 $55^{\circ} \mathrm{C}$ 에서 2시간 반응시킨다. $5 \mathrm{M} \mathrm{NaCl}$ 은 $10 \%$ CTAB buffer에 처 리하여 총 부피의 $1 / 10$ 이 되게 한다. 그 후 $65^{\circ} \mathrm{C}$ 에 1 2시간 처리하였다. PCR을 이용하여 rDNA cluster를 증폭하였으며, ITS region을 증폭하기 위하여 White et al [24]에 보고된 방법 을 이용하여 100 pmole의 ITS 1 (5'-TCC GTA GGT GAA CCT GCG G-3')과 ITS 4 (5'-TCC TCC GCT TAT TGA TAT GC-3') 를 사용하였다. SSU rRNA gene, $5.8 \mathrm{~S}$ rRNA gene, LSU rRNA gene, IGS 1 region, 5S rRNA gene, IGS 2 region을 증폭하기 위하여 사용한 primer는 23개로 Table 2에 명시되어있다. 50 ul의 부피로 10x Ex Taq buffer (20 mM Tris- $\mathrm{HCl} \mathrm{pH} \mathrm{8.0,} 100$ $\mathrm{mM} \mathrm{KCl}, 0.1 \mathrm{mM}$ EDTA, $1 \mathrm{mM}$ DTT), $2.5 \mathrm{mM}$ dNTP mixture, 100 pmol primer, sterilized distilled water, Ex Taq polymerase (TaKaRa Co.)를 첨가하여 PCR로 증폭하였다. SSU rRNA gene, LSU rRNA gene과 IGS region은 사이즈가 크기 때문에 직접 디자인한 primer를 이용하여 증폭하였다(Table 2). PCR 반응 조건은 $95^{\circ} \mathrm{C}, 2$ 분간 predenaturation한 후, $95^{\circ} \mathrm{C}$ 에 1 분간 denaturation, annealing 온도는 각 primer의 조건에 맞게 설 정한 후, $72^{\circ} \mathrm{C}$ 에서 3 분 extension한 후, 25 cycle 증폭하고, 마지 막으로 $72^{\circ} \mathrm{C}$ 에서 5 분간 extension시켰다.

\section{느티만가닥버섯의 rDNA-ITS 영역의 염기서열 분석}

$\mathrm{PCR}$ 로 증폭한 산물을 확인하기 위하여 $0.5 \mathrm{x} \mathrm{TAE}$ 에 $0.7 \%$ agarose를 첨가한 겔 상에 $\lambda$ DNA-HindIII Digest와 함께 전기 영동 하였다. Ethidium Bromide (EtBr)로 염색하여 UV light 상에서 증폭한 DNA band를 확인하였다. 정확하게 증폭된 증 폭산물을 gel에서 회수하여 Gene cloning kit (Qiagen Co.)를 이용하여 정제하였으며, 그 뒤 얻은 이들 유전자 단편을 $\mathrm{pGEM}$ T-easy vector system (Promega Co.)에 삽입하였다. DH5 a (HIT Competent cell ; Donginbiotech Co.)에 형질전환 시켰으 며, ampicillin을 첨가한 $\mathrm{LB}$ 고체 배지에 도말하여 $37^{\circ} \mathrm{C}, 14 \sim 16$ 시간 배양하여 white colony를 선발하였다. 형질 전환된 colony를 한 strain당 8 개를 무작위적으로 선발하여 $3 \mathrm{ml}$ 의 LB ( $1 \%$ tryptone, $0.5 \%$ yeast extract, $1 \% \mathrm{NaCl}, \mathrm{pH} 7.2)$ 액체배지 
에 $37^{\circ} \mathrm{C}$ 에서 16 시간 진탕 배양 한 후, plasmid mini-prep kit (Solgent Co.)를 이용하여 재조합 plasmid DNA를 분리 정제 하였다. 팽이버섯의 rDNA cluster 증폭산물의 염기서열을 분 석하기 위하여 분리한 plasmid DNA를 T7과 SP6 primer를 이용하여 염기서열 분석하고, 각 시료의 $\mathrm{rDNA}$ region 염기서 열을 확정하였다.

\section{느티만가닥버섯의 2차 구조 분석}

Jukes와 Cantor [7]의 방법을 이용하여, DNAstar software (Lasergene Co.)의 MegAlign program을 이용하여 H. marmoreus 3-10 균주과 $H$. marmoreus 1-1 균주의 rDNA-ITS region 염기서열을 CLUSTAL X algorithm으로 정렬하였다[1]. 각 시료 rDNA-ITS 염기서열인 ITS $1,5.8 S$, ITS 2 영역은 NCBI (National Center for Biotechnology Information)의 GenBank (http://www.ncbi.nlm.nih.gov/Genbank)에 등록된 염기서 열과 비교한 후, 결정하였다. 두 균주의 ITS region의 2차구조
분석은 mFold (http://frontend.bioinfo.rpi.edu/applicaions/ $\mathrm{mfold} / \mathrm{cgi}$-bin/rna-form1.cgi)에 의해 산출되었다. 본 연구에 서는 ITS region에 포함되는 ITS 1과 ITS 2, 5.8S가 2차 구조 분석에 사용되었다.

\section{결과 및 고찰}

\section{rDNA cluster의 염기서열 분석}

$H$ marmoreus 3-10 균주와 $H$ marmoreus 1-1 균주의 rDNAcluster의 염기서열을 얻기 위하여 universal primer인 ITS 1 과 ITS 4 를 포함한 23개의 primer를 디자인하였다(Table 1). 두 균주의 rDNA-cluster의 염기서열을 확보하고자 $\mathrm{PCR}$ 산물을 증폭하여 분석한 결과는 Table 2에 나타내었으며, 이들 $H$. marmoreus 3-10 균주와 H. marmoreus 1-1 균주의 rDNA-cluster는 Small subunit gene (SSU), ITS 1, 5.8S rDNA gene, ITS 2, Large subunit gene (LSU), Intergenic spacer 1 (IGS 1), $5 S$

Table 1. A list of major primers used in this study

\begin{tabular}{|c|c|c|c|c|}
\hline Primer name & Sequence $\left(5^{\prime} \rightarrow 3^{\prime}\right),\left(5^{\prime} \leftarrow 3^{\prime}\right)$ & GC $(\%)$ & $\mathrm{Tm}$ & Length (bp) \\
\hline SR1R(1) & $\left(5^{\prime} \rightarrow 3^{\prime}\right)$ TACCTGGTTGATTCTGCCAGT & 47.6 & 51.2 & 21 \\
\hline NS4(1) & $\left(5^{\prime} \leftarrow 3^{\prime}\right) \quad$ CTTCCGTCAATTCCTTTAAG & 40.0 & 46.2 & 20 \\
\hline NS3(2) & $\left(5^{\prime} \rightarrow 3^{\prime}\right)$ GCAAGTCTGGTGCCAGCAGC & 65.0 & 58.1 & 20 \\
\hline NS8(2) & $\left(5^{\prime} \leftarrow 3^{\prime}\right)$ TCCGCAGGTTCACCTACGGA & 60.0 & 57.7 & 20 \\
\hline $\operatorname{ITS1}(4)$ & $\left(5^{\prime} \rightarrow 3^{\prime}\right) \quad$ TCCGTAGGTGAACCTGCGG & 63.2 & 55.7 & 19 \\
\hline ITS4(4) & $\left(5^{\prime} \leftarrow 3^{\prime}\right) \quad$ TCCTCCGCTTATTGATATGC & 45.0 & 49.6 & 20 \\
\hline $5.8 \mathrm{SR}(5)$ & $\left(5^{\prime} \rightarrow 3^{\prime}\right) \quad$ TCGATGAAGAACGCAGCG & 55.6 & 53.0 & 18 \\
\hline LR16(5) & $\left(5^{\prime} \longleftarrow 3^{\prime}\right) \quad$ TTCCACCCAAACACTCG & 52.9 & 46.4 & 17 \\
\hline LROR(6) & $\left(5^{\prime} \rightarrow 3^{\prime}\right) \quad$ ACCCGCTGAACTTAAGC & 52.9 & 44.7 & 17 \\
\hline LR6(6) & $\left(5^{\prime} \leftarrow 3^{\prime}\right) \quad$ CGCCAGTTCTGCTTACC & 58.8 & 45.9 & 17 \\
\hline LR3R(7) & $\left(5^{\prime} \rightarrow 3^{\prime}\right) \quad$ GTCTTGAAACACGGACC & 52.9 & 41.7 & 17 \\
\hline LR10(7) & $\left(5^{\prime} \leftarrow 3^{\prime}\right) \quad$ AGTCAAGCTCAACAGGG & 52.9 & 41.7 & 17 \\
\hline LR8R(8) & $\left(5^{\prime} \rightarrow 3^{\prime}\right) \quad$ AGCAGGTCTCCAAGGTG & 58.8 & 44.4 & 17 \\
\hline 5SRNA(8) & $\left(5^{\prime} \leftarrow 3^{\prime}\right) \quad$ ATCAGACGGGATGCGGT & 58.8 & 50.4 & 17 \\
\hline LR12R(9) & $\left(5^{\prime} \rightarrow 3^{\prime}\right)$ GAACGCCTCTAAGTCAGAATCC & 50.0 & 51.5 & 22 \\
\hline $\operatorname{invSR1R}(9)$ & $\left(5^{\prime} \longleftarrow 3^{\prime}\right)$ ACTGGCAGAATCAACCAGGTA & 47.6 & 51.2 & 21 \\
\hline F.v up2(3) & $\left(5^{\prime} \rightarrow 3^{\prime}\right)$ GCAACGGCAGCTTGTTACTGAGAA & 50.0 & 59.5 & 24 \\
\hline F.v dn $4(3)$ & $\left(5^{\prime} \longleftarrow^{\prime}\right)$ CCCAGACGTGCACGTACGAAGAC & 58.3 & 61.5 & 24 \\
\hline F.v up7 & $\left(5^{\prime} \rightarrow 3^{\prime}\right)$ CGTGGAGGTTTGTGAAGAAGCCTT & 50.0 & 59.6 & 24 \\
\hline F.v up8 & $\left(5^{\prime} \rightarrow 3^{\prime}\right)$ CATTGTCAGGTGGGGAGTTTGGCT & 54.2 & 62.0 & 24 \\
\hline F.vup9 & $\left(5^{\prime} \rightarrow 3^{\prime}\right)$ CATAAGATTCGCTTGTTCGCAACA & 41.7 & 58.1 & 24 \\
\hline F.v up8-2 & $\left(5^{\prime} \rightarrow 3^{\prime}\right)$ TCCTTCTCCGTGTCTTATACTTAG & 41.7 & 48.8 & 24 \\
\hline F.v up9-2 & $\left(5^{\prime} \rightarrow 3^{\prime}\right)$ GGTAAGTAGGCATAAAAGGCTGTT & 41.7 & 52.4 & 24 \\
\hline
\end{tabular}

Table 2. Different nucleotide sequences of $H$. marmoreus 3-10 and H. marmoreus 1-1

\begin{tabular}{cccccc}
\hline Sample strain $^{\mathrm{a}}$ & \multicolumn{5}{c}{ Different nucleotide sequence $(\mathrm{bp})^{\mathrm{b}}$} \\
\hline Hm 3-10and & 18S rDNA & ITS region & $5.8 \mathrm{~S}$ rDNA & $28 \mathrm{~S}$ rNA & IGS 1 region \\
$H$ Hm 1-1 & $2 / 1,796$ & $3 / 615$ & $0 / 153$ & $9 / 3,348$ & $3 / 390$ \\
\hline
\end{tabular}

${ }^{a}$ Comparison of the different nucleotide sequences determining from $H$. marmoreus 3-10 and H. marmoreus $1-1$ was indicated. ${ }^{b}$ Of the total sequences of each region in rDNA cluster, we determined the number of different sequences. The results were yielded using the Meg align program of Lasergene (CLUSTAL W) 


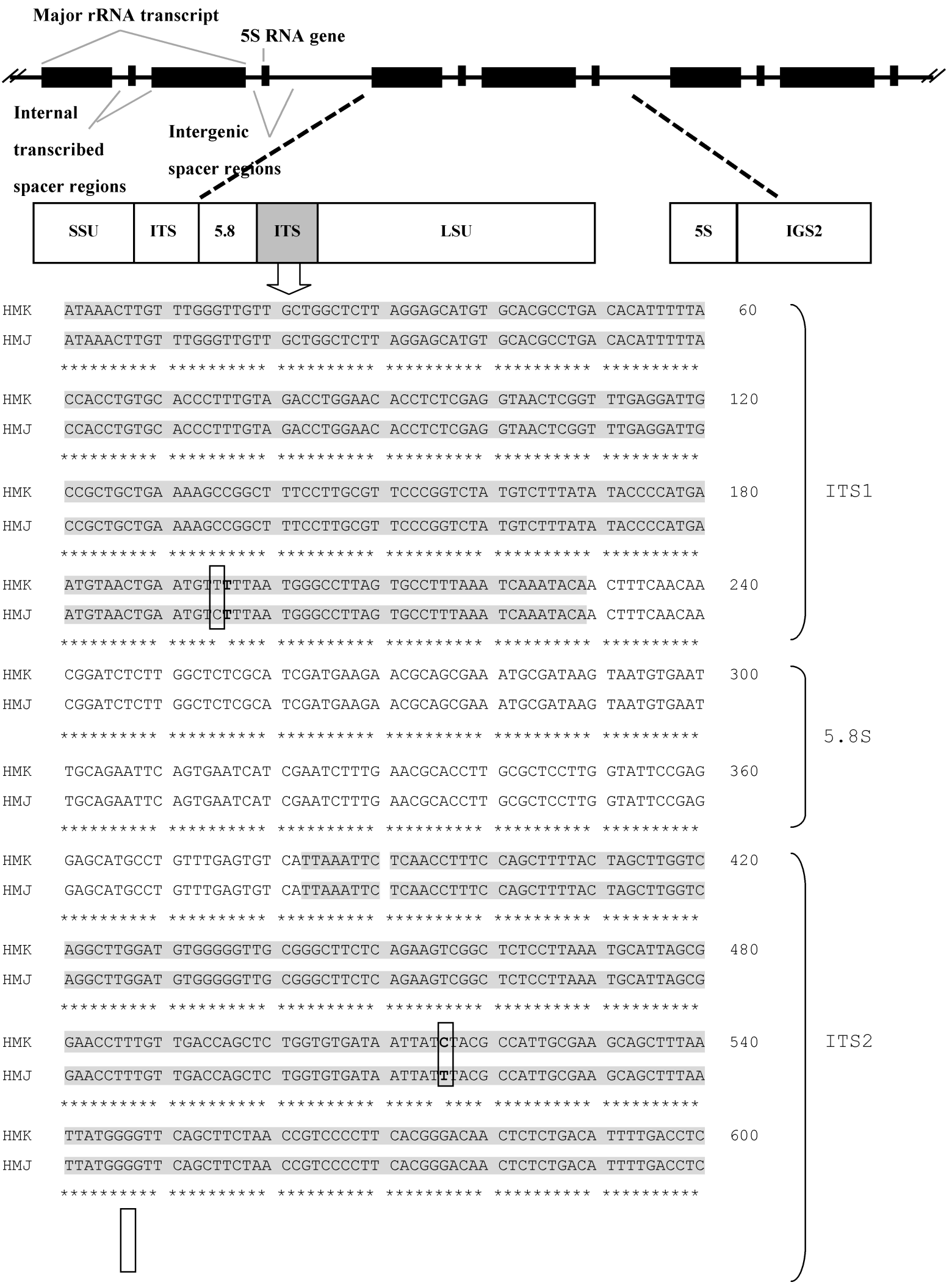

Fig. 1. Aligned nucleotide sequence of Internal transcribed spacer 1, 5.8S, Internal transcribed spacer 2 region of $H$. marmoreus 3-10 and H. marmoreus 1-1. Different nucleotide sequences between $H$. marmoreus 3-10 and $H$ marmoreus 1-1 are indicated by the box. The conserved nucleotides in the internal transcribed spacer region of the two sequences are framed in an asterisks $\left.{ }^{*}\right)$. HMK: H marmoreus 3-10, HMJ: H marmoreus 1-1. 
rDNA, 및 Intergenic spacer 2 (IGS 2)로 구성되어 있다.

$\mathrm{SSU}$ 에 속하는 $18 \mathrm{~S} \mathrm{rDNA}$ 는 $1,796 \mathrm{bp}$ 였고, $\mathrm{LSU}$ 에 해당하는 $28 \mathrm{~S} \mathrm{rDNA}$ 는 $3,348 \mathrm{bp}$ 임을 확인하였다. 변이가 발생하는 ITS 1 과 ITS 2는 각각 $229 \mathrm{bp}, 233 \mathrm{bp}$ 였고, 보존적인 $5.8 \mathrm{~S}$ 영역은 $153 \mathrm{bp}$ 임을 확인하였으며, ITS 영역의 nucleotide 서열은 Fig. 1 에서 정렬하였다. 따라서 본 연구에서 2 차구조 분석에 이용 된 ITS 영역은 총 $462 \mathrm{bp}$ 로 염기배열이 결정 되었으며, IGS 1은 $390 \mathrm{bp}, \mathrm{IGS}$ 2는 $900 \mathrm{bp}$ 임을 확인하였다. rDNA-cluster는 H. marmoreus 3-10 균주와 H. marmoreus 1-1 균주가 동일하게 $7,049 \mathrm{bp}$ 로 결정되었다.

rDNA cluster의 염기서열 결과는, NCBI (National center for Biotechnology Information)의 GenBank (http://www. ncbi.nlm.nih.gov/Genbank/)에 서열을 기탁하여 국내 개발 균주인 H. marmoreus 3-10 (Accession No. KF150213)과 일본 유래 균주인 H marmoreus 1-1 (Accession No. KF192813)의 Accession No.를 받았다. 총 7,049 bp 중, 서열상에서 길이의 차이는 없었으나, 염기서열의 차이가 확인되었다. SSU에서 2 개, ITS에서 3개, LSU에서 9개, IGS에서 3개 염기가 상이하다 는 결과를 확인하였다(Table 2). 가장 큰 변이율을 나타내는 영역은 $1.46 \%$ 를 나타낸 ITS 영역임을 확인하였다. SSU는 $0.11 \%, \mathrm{LSU}$ 는 $0.26 \%$, IGS 영역은 $0.32 \%$ 의 변이율을 확인하였 다. 따라서 총 $7,049 \mathrm{bp}$ 중에서 17 개 염기서열이 다른 것을 알 수 있었으며, 느티만가닥버섯에서 가장 보존적인 영역은 $\mathrm{SSU}$ 영역과 $5.8 \mathrm{~S} \mathrm{rDNA}$ 영역임이 확인되었다.

최근에는 fungi에서 ITS 영역을 이용한 연구가 많이 이루어 졌다. Lentinus edodes의 경우, 균주 간에는 ITS 영역의 염기서 열 차이가 없었으나 L. edodes와 L. boryana 등의 종간에는 큰
차이를 보였다고 하였으며, 느타리버섯에서는 $\mathrm{rDNA}$-ITS의 염기서열이 종(species) 구분에 적당하다는 연구 결과가 있었 다. 또한, Dictyophora 균에서 배양적 특성, 재배적 특성과 형 태적 특성을 종합하여 보았을 때 거의 일치하는 경향을 보임 으로써, $\mathrm{rDNA}$ ITS 영역을 통한 분자생물학적 분석을 이용하 는 방법이 종 구분에 유용할 것이라는 보고가 있었다[5]. 또한 ITS 영역을 이용한 다른 연구로 상황버섯에서 $\mathrm{rDNA}$ 의 ITS 영역에 대해 종이나 품종간 특이한 염기서열의 존재가 확인되 면 이를 primer 제작하여 종 수준의 동정에 활용이 가능하다 고 한 연구 결과가 있다 $[9,16]$.

이처럼 DNA barcode를 이용한 SNP (single nucleotide polymorphism)분석법은 쉽고 간편하며 PCR을 통한 증폭 산 물의 사이즈가 적을 뿐 아니라, 재현성과 염기서열분석의 신 뢰도가 높은 장점이 있다. 또한 $0.1 \%$ 의 $\mathrm{SNP}$ 차이는 질병의 유 무나 표현형의 다양성을 이끈다. 본 연구와 같이 유연관계가 같거나 비슷한 개체의 판별에는 DNA barcode를 이용한 SNP 분석법이 유용하게 사용될 것으로 사료된다.

앞서 설명한 바와 같이 두 균주의 염기서열에 기초한 alignment 결과에서 3 개 상이한 염기서열이 2차 구조 형성에 어떠 한 영향을 끼치는지 알아보고자 2차 구조 분석을 수행하였다. Fig. 2에서는 H marmoreus 3-10 균주와 H marmoreus 1-1 균주 의 ITS region의 염기서열을 이용하여 $\mathrm{mFold}$ 프로그램을 통한 2차 구조 분석을 수행한 것이다. 이들 균주의 ITS region은 5 개 stem-loop 구조를 갖고 있음을 확인하였다. ITS 1 영역에 서 나타난 한 개 염기서열 차이는 stem-loop V에서 볼 수 있듯 이 2차 구조 형성에는 어떠한 영향도 주지 않음을 확인 할 수 있었다. Fig. 2B를 보면 화살표로 나타낸 부분이 상이한

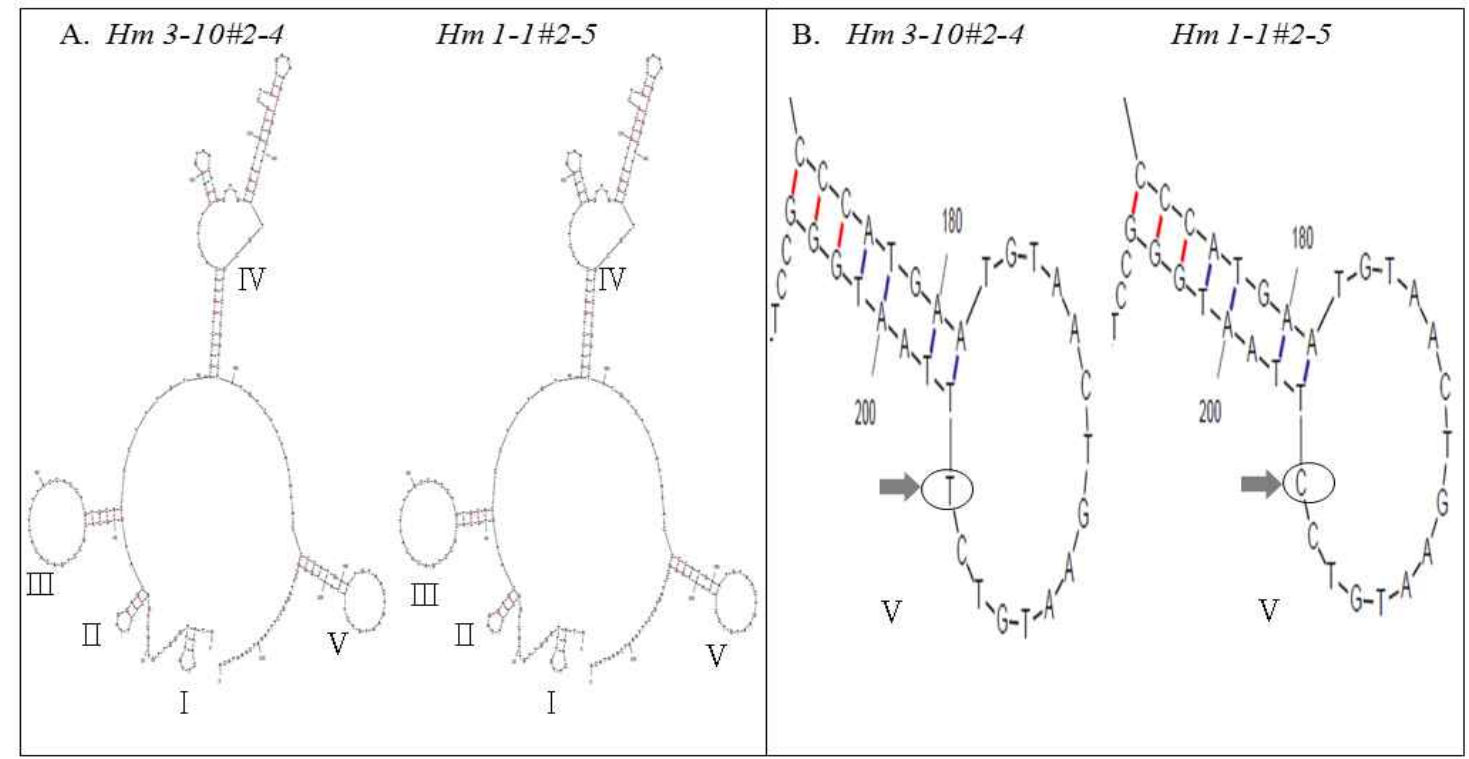

Fig. 2. Secondary structures of internal transcribed spacer 1 from $H$. marmoreus 3-10 and $H$. marmoreus 1-1. Five stem-loop structures were found in internal transcribed spacer 1 region. Despite different nucleotide of $H$. marmoreus 3-10 and H. marmoreus 1-1, stem-loop $\mathrm{V}$ has same secondary structure. Locations of different nucleotides are indicated by arrows. 


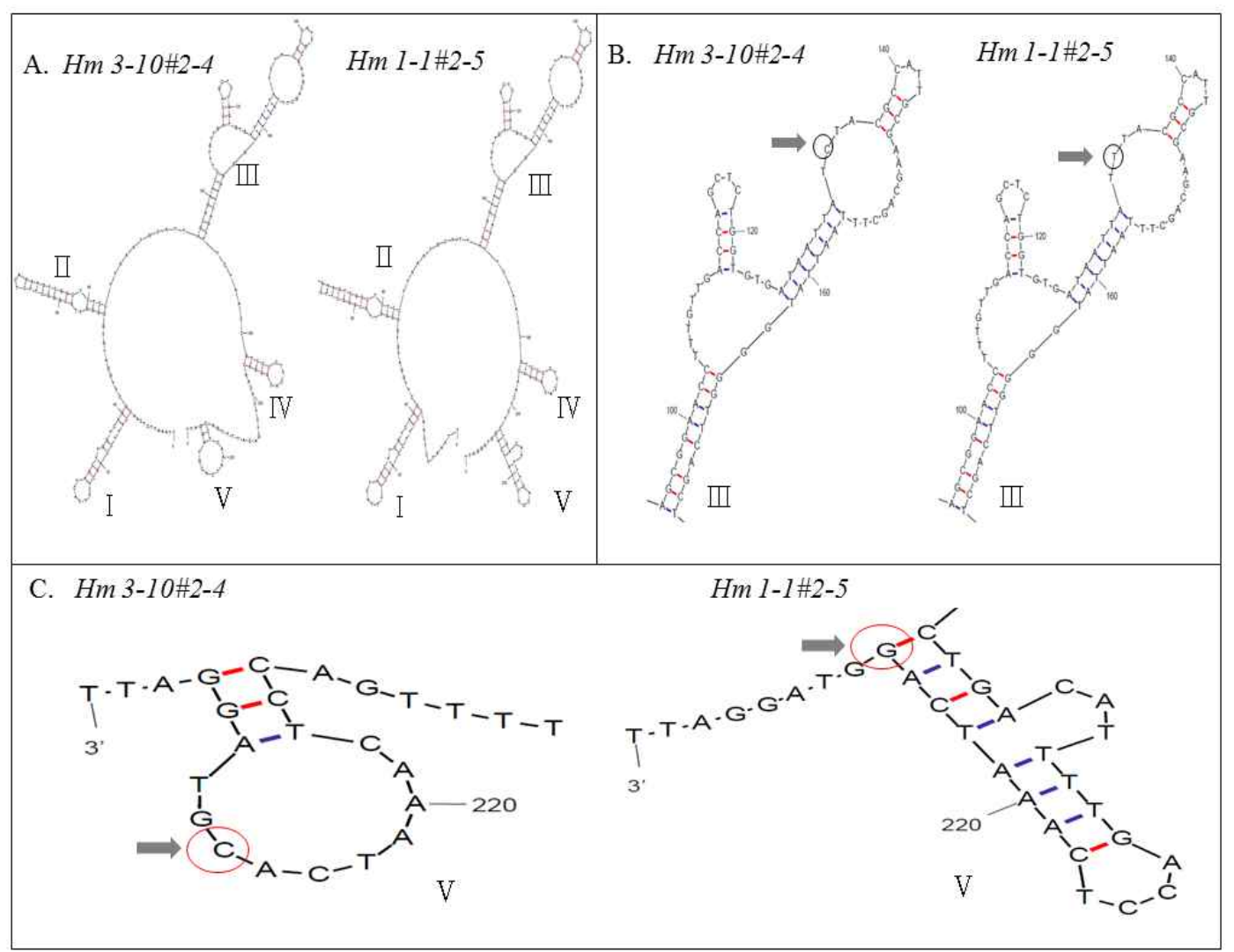

Fig. 3. Secondary structures of internal transcribed spacer 2 from $H$. marmoreus 3-10 and H.marmoreus 1-1. A. Five stem-loop structures were found in internal transcribed spacer 2 regions. B. Despite different nucleotide of $H$. marmoreus 3-10 and H. marmoreus 1-1, stem-loop III has same secondary structure. Locations of different nucleotides are indicated by arrows. C. Due to one nucleotide differences, stem-loop $\mathrm{V}$ showed different secondary structure.

염기임을 알 수 있다. Fig. 3A는 ITS 2 region의 전체 2차 구조 를 나타내며, stem-loop III에서 한 개의 상이한 염기가 2차 구조에 영향을 끼치지 않음을 알 수 있었다. 하지만 stem-loop $\mathrm{V}$ 을 보면 훙미롭게도 한 개의 염기 차이로 인하여 2차 구조 folding 패턴이 두 균주에서 명확하게 구분되었다.

본 연구는 국내 균주 H. marmoreus 3-10 균주와 일본 균주 $H$ marmoreus 1-1 간의 $\mathrm{rDNA}$ cluster에 기반한 염기서열 분석 을 최초로 수행하였으며, 두 느티만가닥버섯 균주의 multiple alignment를 통하여 염기서열 차이를 확인하였다. 이에 ITS 염기서열은 지리학적 차이로 인하여 유의한 차이가 있음을 확인하였고, 국내 개발 균주와 일본 균주의 비교분석에 이용 될 자료로 적합하다고 생각된다. 또한 느티만가닥 버섯의 균 주들을 구별하기 위한 마커를 개발하기 위하여 분자유전학적 방법인 RAPD (Random amplified polymorphism), AFLP (Amplified fragment length polymorphic DNA) 등의 보완연 구가 필요할 것으로 판단된다.

\section{감사의 글}

본 연구는 농림수산식품기술기획평가원 농림기술개발사업
과 버섯수출사업단에서 연구비를 지원받았기에 이에 감사 드 립니다.

\section{References}

1. Akavia, E., Beharav, A., Wasser, S. P. and Nevo, E. 2009. Disposal of agro-industrial by-products by organic cultivation of the culinary and medicinal mushroom Hypsizygus marmoreus. Waste Manag 29, 1622-1627.

2. Alam, N., Shim, M. J., Lee, M. W., Shin, P. G., Yoo, Y. B. and Lee, T. S. 2009. Physiologenetic relationship in different commercial strains of Pleurotus nebredonsis based on ITS sequence and RAPD. Mycobiology 37, 183-188.

3. Bao, H., Choi, W. S. and You, S. 2010. Effect of sulfated modification on the molecular characteristics and biological activities of polysaccharides from Hypsizigus marmoreus. Biosci Biotechnol Biochem 74, 1408-1414.

4. Chen, S. L., Yao, H., Han, J., Liu, C., Zhu,Y., Ma, X., Gao, T., Pang, X., Luo, K., Li, X. Li, X., Jia, X., Lin, Y. and Leon, C. 2010. Validation of the ITS2 region as a novel DNA barcode for identifying medicinal plant species. PLos One 5, e8613.

5. Cheong, J. C., Kim, G. P., Kim, H. K., Park, J. S. and Chung, 
B. K. 2000. Cultural characteristics of veiled lady mushroom, Dictyophora spp. Mycobiology 28, 165-170.

6. Ikekawa, T. 1995. Bunashimeji, Hypsizygus marmoreus antitumor activity of extracts and polysaccharides. Food Rev Int 11, 207-209.

7. Jukes, T. H. and Cantor, C. R. 1969. Evolution of protein molecules. In: Munro, H. N. (ed.), pp. 21, Mammalian protein metabolism, II. New York Academic Press.

8. Kimura, M. 1980. A simple method for estimating evolutionary rates of base substitutions through comparative studies of nucleotide sequences. J Mol Evol 16, 111-120.

9. Lee, Y. S., Kim, N. W. and Kim, J. B. 2012. Genetic variation based on random amplified polymorphic DNA (RAPD) and Internal Transcribed Spacer (ITS) region sequences in Lepista nuda. J Life Sci 22, 1470-1476.

10. Matsuzawa, T., Sano, M., Tomita, I., Saitoh, J. and Ikekawa, T. 1997. Studies on antioxidant effect of Hypsizigus marmoreus. I. Effects of Hypsizigus marmoreus for antioxidant activities of mice plasma. Yakugaku Zasshi 117, 623-628.

11. Mello, A., Ghignone, S., Vizzini, A., Sechi, C., Ruiu, P. and Bonfante, P. 2006. ITS primers for the identification of marketable boletes. J Biotechnol 121, 318-329.

12. Miyashita, M., Sakane, T., Suzuki, K. and Nakagawa, Y. 2008. 16S rDNA gene and 16S-23S rRNA gene internal transcribed spacer sequences analysis of the genus Myxococcus. FEMS Microbiol Lett 282, 241-245.

13. Moradali, M. F., Mostafavi, H., Ghods, S. and Hedgaroude, G. A. 2007. Immunomodulating and anticancer agent in the realm of macromycetes fungi (macrofungi). Int Immunopharmacol 7, 701-724.

14. Mori, K., Kobayashi, C., Tomita, T., Inatomi, S. and Ikeda, M. 2008. Antiatherosclerotic effect of the edible mushroom Pleurotus eryngii, Grifola frondosa, and Hypsizygus marmoreus in apolipoprotein E-deficient mice. Nutr Res 28, 335-342.

15. Nakamura, K. 2006. Bottle cultivation of culinary-medicinal Bunashimeji mushroom Hypsizygus marmoreus (Peck) bigel.
(Agaricomycetideae) in Nagano Prefecture (Japan). Int J Med Mushr 8, 179-186.

16. Park, D. S., Kang, H. W., Kim, K. T., Cho, S. M., Park, Y. J., Shin, H. S., Lee, M. B. and Go, S. J. 2001. PCR-based sensitive detection of wood decaying fungus Phellinus linteus by specific primer from rDNA ITS regions. Micobiology 29, 7-10.

17. Ray, P. and Adholeya, A. 2008. Development of molecular markers of ectomycorrhizal fungi based on ITS region. Curr Microbiol 57, 23-26.

18. Royse, D. J. 1995. Specialty mushrooms: cultivation on synthetic substrate in the USA and Japan. Interdisciplin Sci Rev 20, 205-214.

19. Saitou, N. and Nei, M. 1987. The Neighbor-Joining method: a new method for constructing phylogenetic trees. Mol Biol Evol 4, 406-425.

20. Su, H., Wang, L., Liu, L., Chi, X. and Zhang, Y. 2008. Use of inter-simple sequence repeat markers to develop strain-specific SCAR markers for Flammulina velutipes. I Appl Genet 49, 233-235.

21. Uhart, M., Sirand-Pugnet, P. and Labarère, J. 2007. Evolution of mitochondrial SSU-rDNA variable domain sequences and rRNA secondary structures, and phylogeny of the Agrocybe aegerita multispecies complex. Res Microbiol 158, 203-212.

22. Wasser, S. P. 2002. Medical mushrooms as a source of antitumor and immunomodulating polysaccharides. Appl Microbiol Biotechnol 60, 258-274.

23. Won, H. and Renner, S, S. 2005. The internal transcribed spacer of nuclear ribosomal DNA in the gymnosperm Gnetum. Mol Phylogenet Evol 36, 581-597.

24. White, T. J., Burns, T., Lee, S. and Taylor, J. 1990. Amplification and direct sequencing of fungi ribosomal RNA Genes for phylogenetic. In PCR protocols: A guide to methods and amplification. J Academic Press San Diego California 315-322

\section{우주리 ${ }^{1} \cdot$ 윤혁준 $^{1} \cdot$ 유영현 $^{1} \cdot$ 이창윤 ${ }^{2} \cdot$ 공원식 $^{3} \cdot$ 김종국 ${ }^{*}$ \\ ( ${ }^{1}$ 경북대학교 생명과학부, ${ }^{2}$ 그린피스, ${ }^{3}$ 농촌진흥청)}

초록 : 느티만가닥버섯의 ITS (internal transcribed spacer) 영역의 2차구조 분석

본 연구에서는 H. marmoreus 3-10균주와 H. marmoreus 1-1균주의 ribosomal DNA (rDNA) cluster의 분석이 수 행되었다. Small subunit (SSU)와 intergenic spacer 2 (IGS 2)는 부분적으로 염기서열이 결정되었고, internal transcribed spacer 1 (ITS 1), 5.8S, internal transcribed spacer 2 (ITS 2), large subunit (LSU), intergenic spacer 1 (IGS 1), 5S는 완전하게 염기서열이 결정 되었다. 팽이버섯 H. marmoreus 3-10균주와 H. marmoreus 1-1균주의 $\mathrm{rDNA}$ cluster는 총 7,049 bp로 결정되었다. SSU은 $1,796 \mathrm{bp}$, ITS1은 $229 \mathrm{bp}, 5.8 S$ 은 $153 \mathrm{bp}$, ITS2는 $223 \mathrm{bp}$, LSU은 3,348 $\mathrm{bp}, \mathrm{IGS1}$ 은 $390 \mathrm{bp}, \mathrm{IGS} 2$ 은 $900 \mathrm{bp}$ 로 염기서열이 분석되었다. 결정된 rDNA cluster의 총 7,049 bp 중에서 $17 \mathrm{bp}$ 가 다름이 확인되었고, 각각 SSU (2 bp), ITS (3 bp), LSU (9 bp), IGS (3 bp)에서 차이를 확인하였다. ITS regions의 2 차 구조 결과 5 개의 stem-loop가 있음이 드러났다. 흥미롭게도, 이들 stem-loop 사이에서 stem-loopV에서 한 개의 상이한 염기가 다른 2차 구조를 나타냄을 확인하였다. 